\title{
Chlorophyll fluorescence parameters in populations of two legume trees: Stryphnodendron adstringens (Mart.) Coville (Mimosoideae) and Cassia ferruginea (Schrad.) Schrad. ex DC. (Caesalpinoideae)
}

\author{
JOSÉ P. LEMOS FILHO ${ }^{1,3}$, MAÍRA F. GOULART ${ }^{2}$ and MARIA B. LOVATO ${ }^{2}$
}

(received: April 16, 2003; accepted: April 29, 2004)

\begin{abstract}
Chlorophyll fluorescence parameters in populations of two legume trees: Stryphnodendron adstringens (Mart.) Coville (Mimosoideae) and Cassia ferruginea (Schrad.) Schrad. ex DC. (Caesalpinoideae)). The aim of this study was to investigate the photosynthetic performance in populations of two legume tree species, Stryphnodendron adstringens (Mimosoideae), typical from Cerrado, and Cassia ferruginea (Caesalpinoideae) from the Atlantic Rain Forest. The photosynthetic traits were assessed by measures of chlorophyll fluorescence in progenies of naturally pollinated plants from three populations of $S$. adstringens and a population of $C$. ferruginea. Plants of $S$. adstringens growing under similar conditions of $C$. ferruginea plants demanded higher light values for photosynthesis saturation, $600 \mu \mathrm{mol} \cdot \mathrm{m}^{-2} . \mathrm{s}^{-1}$ and $350 \mu \mathrm{mol} . \mathrm{m}^{-2} . \mathrm{s}^{-1}$ respectively, and showed higher intrinsic photosynthetic efficiency of photosystem II, Fv/Fm of 0.814 versus 0.783 in $C$. ferruginea. The highest values of Fv/Fm observed in $S$. adstringens can explain the highest electron transport rates (ETR) obtained for this species. No significant differences were found among progenies from different $C$. ferruginea trees nor among populations of $S$. adstringens, and only in few cases, variation among progenies within populations were found for $S$. adstringens plants. The fact that fluorescence parameters distinguished species but not populations or most of progenies may be related to low intraspecific genetic variation of these chlorophyll fluorescence traits or due to lack of expression on genetic differences in plants under no stressful conditions.
\end{abstract}

Key words - chlorophyll fluorescence, legume trees, population approach, quantum yield

RESUMO - (Parâmetros da fluorescência da clorofila em populações de duas leguminosas arbóreas: Stryphnodendron adstringens (Mart.) Coville (Mimosoideae) e Cassia ferruginea (Schrad.) Schrad. ex DC. (Caesalpinoideae)). O objetivo do estudo foi avaliar a performance fotossintética em populações de duas leguminosas arbóreas, Stryphnodendron adstringens (Mimosoideae), uma espécie típica do Cerrado e Cassia ferruginea (Caesalpinoideae), que ocorre na Mata Atlântica. Os parâmetros de fotossíntese foram obtidos por medições de fluorescência da clorofila em progênies de plantas naturalmente polinizadas provenientes de três populações de $S$. adstringens e de uma população de $C$. ferruginea. Plantas de $S$. adstringens crescendo sob as mesmas condições que plantas de $C$. ferruginea, demandaram, comparativamente, valores mais elevados de luz para a saturação da fotossíntese, respectivamente $600 \mu \mathrm{mol} \cdot \mathrm{m}^{-2} . \mathrm{s}^{-1} \mathrm{e} 350 \mu \mathrm{mol} . \mathrm{m}^{-2} . \mathrm{s}^{-1}$, e apresentaram uma mais elevada eficiência intrínseca do fotossistema II, Fv/Fm de 0,814 versus 0,783 em C. ferruginea. Os maiores valores de Fv/Fm observados em $S$. adstringens podem explicar as maiores taxas relativas de transporte de elétrons (ETR). Não foram encontradas diferenças significativas entre progênies das árvores de $C$. ferruginea, nem entre populações de $S$. adstringens, e apenas algumas poucas diferenças entre progênies dentro de populações de $S$. adstringens. O fato de parâmetros da fluorescência da clorofila distinguir espécies, mas não populações ou progênies pode estar relacionado à baixa variação genética destes caracteres de fluorescência da clorofila ou devido a ausência da expressão das diferenças genéticas em plantas sob condições não estressantes.

Palavras-chave - abordagem populacional, fluorescência da clorofila, leguminosas arbóreas, rendimento quântico

\section{Introduction}

Several studies on photosynthesis of neotropical species can be found in the literature (e.g. Hogan et al. 1995, Valadares et al. 1997, Allen \& Pearcy 2000,

\footnotetext{
1. Universidade Federal de Minas Gerais, Instituto de Ciências Biológicas, Departamento de Botânica, Av. Antônio Carlos, 6627, 31270-010 Belo Horizonte, MG, Brazil.

2. Universidade Federal de Minas Gerais, Instituto de Ciências Biológicas, Departamento de Biologia Geral, Av. Antônio Carlos, 6627, 31270-010 Belo Horizonte, MG, Brazil.

3.
}

Lemos Filho 2000) and most of them emphasize differences among species and/or responses to different environmental conditions. Specifically in Brazil, studies on photosynthesis of woody species have been performed mainly for cerrado plants, and were reviewed by Mattos (1998), Moraes \& Prado (1998), Paulilo \& Felipe (1998) and Franco (2000). In general, these ecophysiological studies use gas exchange methodology and point out to a significant decrease of net photosynthesis due stomatal conductance limitations, mainly during dry season. Moraes \& Prado (1998) and Paulilo \& Felipe (1998) presented photosynthetic data for many cerrado species and compared them with plants 
from different biomes, while Franco (2000) presented data comparing evergreen, briefly deciduous and deciduous cerrado species.

Comparative studies using chlorophyll fluorescence measurements have also been published in Brazil, most of them about cerrado species. These works include comparison of mistletoes photosynthesis in relation to their hosts (Lüttge et al. 1998), photoinhibition (Lemos Filho 2000) and more recently, for Miconia albicans, rapid changes in photosynthetic behaviour due to overnight rainfall at a dry spell amidst in the rainy season have been shown by Mattos et al. (2002). Despite their relevance, all ecophysiological and species comparative studies of photosynthesis, using both gas exchange or chlorophyll fluorescence, usually use samples with a few plants as representative of species behaviour.

As pointed by Arntz \& Delph (2001), a population level perspective is necessary to assess one of the requirements for evolution by natural selection, which is the presence of variation for a given trait within a population. Thus, although studies of photosynthesis at a population level seem to be necessary for the understanding of adaptive evolution to different environments, this approach has not been taken for neotropical wood species.

In the present study we analyse the photosynthetic performance of progenies of naturally pollinated plants from different populations of two legume tree species, Stryphnodendron adstringens (Mimosoideae) and Cassia ferruginea (Caesalpinoideae), which are typical from cerrado and Atlantic forest respectively, evaluating photosynthesis through measurements of chlorophyll fluorescence.

\section{Material and methods}

The study was carried out with plants that were obtained from seeds collected from randomly chosen naturally pollinated plants in Southeastern region of Brazil. For Stryphnodendron adstringens, three populations were evaluated, one from Piraju, São Paulo State, and the others from Furnas and Gouvea, from Minas Gerais State. For Cassia ferruginea a single population from Parque Estadual do Rio Doce (PERD), Minas Gerais State, was analysed. In $S$. adstringens, the progenies of six trees from Piraju, four from Gouveia and five from Furnas were evaluated. In C. ferruginea, the progenies of 13 trees from PERD were evaluated. The experiment was performed in three entirely randomised block design. The seeds were scarified and germinated on the temperature of $28 \pm 1^{\circ} \mathrm{C}$ in the darkness. Six days later, seedlings with uniform development were selected and planted in $500 \mathrm{~mL}$ pots with a loamy dystrophic soil. After 10 weeks of sowing, each plant was supplied with $80 \mathrm{~mL}$ of half-strength Hoagland solution. In the glasshouse, the photosynthetic photon flux density (PPFD), determined with a LI-COR quantum sensor, was of about 200 to $400 \mu \mathrm{mol} . \mathrm{m}^{-2} . \mathrm{s}^{-1}$, measured between 9 to $11 \mathrm{am}$. After twenty weeks of growth, the plants were moved to a growing room and kept under temperature of $27 \pm 2{ }^{\circ} \mathrm{C}$, relative air humidity of about $60 \pm 10 \%, 12$ hours photoperiod with $60 \mu \mathrm{mol} . \mathrm{m}^{-2} . \mathrm{s}^{-1}$ of PPFD, provided by daylight F40D fluorescent lamps (OSRAM, USA). Those conditions are similar to the ones utilised by Queiroz et al. (2001).

After two days of adaptation to those environmental conditions, fluorescence parameters were determined in the central leaflet from the penultimate mature leaf, in order to avoid differences due to the ontogenetic stage, as recommended by Šesák \& Šiffel (1997). Between one to four plants from each mother tree in each block were evaluated. At the end of the subjective night, the chlorophyll $a$ fluorescence measurements were performed with a pulse amplitude modulated photosynthesis yield analyser (MiniPAM, Walz, Germany), obtaining the minimal fluorescence yield (Fo) and the maximum fluorescence during a pulse saturating irradiance $(\mathrm{Fm})$, which allowed the determination of the potential quantum yield of photosystem II (PSII), $\mathrm{Fv} / \mathrm{Fm}=(\mathrm{Fm}-\mathrm{Fo}) / \mathrm{Fm}$. Light saturation curves were also obtained using the light curve program of the instrument, evaluating one plant from each mother tree, in each block. Actinic light on leaves was increased up to ca. $2000 \mu \mathrm{mol} . \mathrm{m}^{-2} . \mathrm{s}^{-1}$ during 4 minutes in 8 steps of 30 seconds each. At each level of light supplied by the instrument, a pulse saturating irradiance was applied to obtain chlorophyll fluorescence parameters. The effective quantum yield is given as $\Delta \mathrm{F} / \mathrm{F}^{\prime} \mathrm{m}=(\mathrm{F}$ ' $\mathrm{m}$ - F $) / \mathrm{F}^{\prime} \mathrm{m}$, where $\mathrm{F}$ is the minimal chlorophyll fluorescence of the light adapted leaf and F'm the maximum light adapted fluorescence during a saturating light pulse. Apparent photosynthetic electron transport rates (ETR) are given as $0.5 \times \Delta \mathrm{F} / \mathrm{F}^{\prime} \mathrm{m} \times \mathrm{PPFD}$, and the relative excessive PPFD was obtained as (Fv/Fm - $\left.\Delta \mathrm{F} / \mathrm{F}^{\prime} \mathrm{m}\right) /(\mathrm{Fv} / \mathrm{Fm})$ (Bilger et al. 1995). In a study using a similar light curve program, Lüttge et al. (1998) pointed that due to the short time of light exposition in each step the photosynthesis of leaves was never in steady state and correct absolute values of ETR were not obtained. However, they considered that comparative assessments of photosynthetic performance of leaves are still valid.

Due to time limitations, one experimental block was analysed per day. Light saturation curves of fluorescence parameters were fitted using the software Graph Pad Prism. For all chlorophyll fluorescence parameters evaluated, mean and standard deviation were calculated for each population of $S$. adstringens and for $C$. ferruginea and compared by Analysis of Variance (ANOVA). Principal Component Analysis (PCA), using the software Pcord v.4, was carried out to investigate possible associations among the evaluated traits and differences among populations and among species. 
In both species $\mathrm{Fv} / \mathrm{Fm}$ data was transformed in $\arcsin \sqrt{ }$ to reach homogeneity of variance.

\section{Results and Discussion}

The curves representing the effective quantum yield $(\Delta \mathrm{F} / \mathrm{F}$ 'm), photosynthetic electron transport rates (ETR) and the relative excessive PPFD determined for $C$. ferruginea and $S$. adstringens are shown respectively in figures 1 and 2. Comparing the two species, the photosynthetic performance was superior
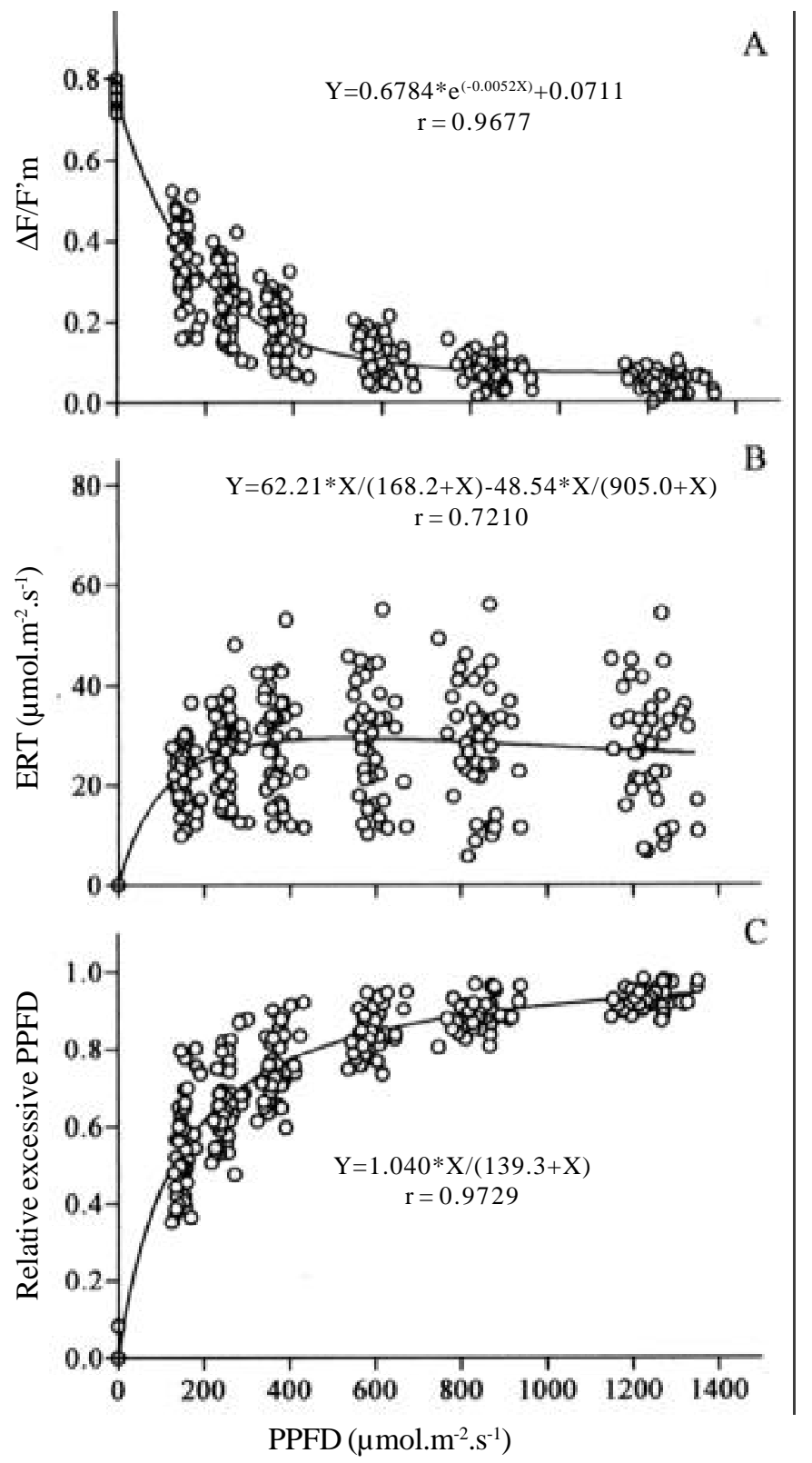

Figure 1. Effective quantum yield ( $\left.\Delta \mathrm{F} / \mathrm{F}^{\prime} \mathrm{m}\right)(\mathrm{A})$, apparent rate of photosynthetic electron transport from photosystem II (ETR) (B), and the relative excessive PPFD (C) in leaves of plants from a population of $C$. ferruginea. in S. adstringens plants, which presented higher values of $\Delta F / F ' m$ and ETR even in lower levels of irradiance. The values of ETR showed that photosynthesis saturated in lower levels of PPDF for $C$. ferruginea (ca. $350 \mu \mathrm{mol} . \mathrm{m}^{-2} . \mathrm{s}^{-1}$ ) when compared to $S$. adstringens (ca. $600 \mu \mathrm{mol} \cdot \mathrm{m}^{-2} \cdot \mathrm{s}^{-1}$ ). However, the values obtained were smaller than the ones described by Lemos Filho (2000), who found values for photosynthesis saturation around $1500 \mu \mathrm{mol} \cdot \mathrm{m}^{-2} \cdot \mathrm{s}^{-1}$ in three species typical from cerrado growing under field conditions. The lower values of light saturation for the two studied species are probably
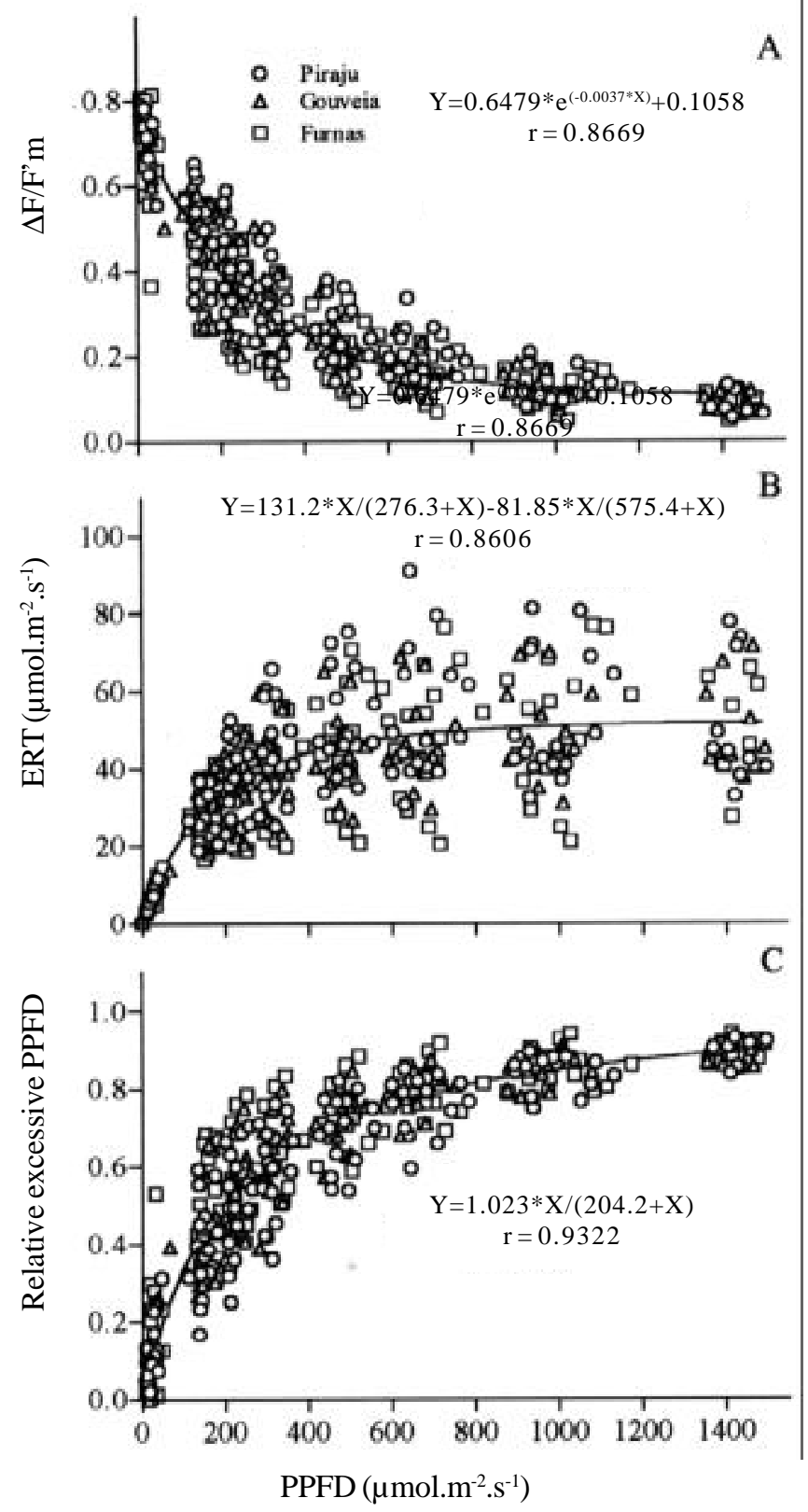

Figure 2. Effective quantum yield $\left(\Delta \mathrm{F} / \mathrm{F}^{\prime} \mathrm{m}\right)(\mathrm{A})$, apparent rate of photosynthetic electron transport from photosystem II (ETR) (B), and the relative excessive PPFD (C) in leaves of plants from three populations of $S$. adstringens. 
related to the low PPFD in the environment where plants were cultivated.

It has been demonstrated that in sun adapted species, light saturation of photosynthesis occurs at higher light intensities than in shade adapted species (Bazzaz 1979). It is shown that compared to $C$. ferruginea, a higher value of radiation necessary for photosynthesis saturation was observed for $S$. adstringens. This fact is possibly related to the environment of natural occurrence of the studied species. In cerrado the canopy is typically discontinuous, and a lower leaf area index (LAI), around 1 in wet season (Miranda et al. 1997), allows a higher availability of light understory. On another hand, in the environment of natural occurrence of C. ferruginea, the Atlantic forest, the canopy is denser and higher LAI values, i.e. 4.9 during the rainy season in a semideciduos forest in Belo Horizonte (Paula \& Lemos Filho 2001), results in lower light availability bellow the forest canopy.

According to the photosynthetic performance, a relative excessive PPFD above of $80 \%$ occurred in lower levels of photosynthetic active radiation for most of $C$. ferruginea plants $\left(\sim 500 \mu \mathrm{mol} \cdot \mathrm{m}^{-2} \cdot \mathrm{s}^{-1}\right)$, while for $S$. adstringens plants, similar excess occurred at higher levels of radiation $\left(\sim 800 \mu \mathrm{mol} \cdot \mathrm{m}^{-2} \cdot \mathrm{s}^{-1}\right)$. Considering that an increase in the excess of photosynthetic active radiation is directly related to an increase of non photochemical quenching (NPQ) (Björkman \& DemmigAdams 1995), it can be concluded that, comparatively with $S$. adstingens, cultivated plants of $C$. ferruginea under shade conditions, present a higher NPQ even when exposed to relatively low levels of irradiance.

When leaves are exposed to more light than can be utilised through the process of photosynthesis, PSII function can be affected in a stress condition known as photoinhibition (Barber \& Anderson 1992). In fact, when considering 0.8 as a threshold value for photoinhibition, as suggested by Lüttge et al. (1998), the measurements show that in average, C. ferruginea plants are photoinhibided (table 1). However, due to the low light level in experimental condition, this would not be possible. In a similar way, Bòlhar-Nordenkampf \& Öquist (1993) reported values of Fv/Fm of 0.725 in non photoinhibided plants of french bean. Although not photoinhibited, compared to $S$. adstringens, plants of C. ferruginea show inferior values of $\mathrm{Fv} / \mathrm{Fm}(\mathrm{p}<0.05)$ and higher values of relative excessive PPFD at a lower light levels (figures 1,2), suggesting that shade adapted plants of this species may suffer greater photoinhibition damages if exposed to upper levels of light.

For all studied fluorescence parameters, significant differences $(p<0.05)$ were found when compared the two species (table 1). Progenies from different trees of C. ferruginea did not differ significantly in fluorescence traits ( $p>0.05)$. S. adstringens populations did not differ for evaluated traits ( $p>0.05)$, although some differences among progenies within populations could be detected $(p<0.05)$. Analysis of variance showed differences among Furnas progenies when Fo values were compared and among Piraju progenies when Fm values were compared. Higher values of intrinsic photosynthetic efficient of photosystem II, given by the ratio $\mathrm{Fv} / \mathrm{Fm}$, were observed in $S$. adstringens when compared to C. ferruginea plants. This higher potential quantum yield of photosystem II could explain the highest values of the maximum apparent rate of photosynthetic electron transport (ETRmax), obtained from the light saturation curve, observed for $S$. adstringens plants.

Most of these results are illustrated in the graph generated by the Principal Component Analysis (figure 3). Together the two factors explained $87.2 \%$ of the total variance. The figure clearly shows differences among the studied species, but within a species, patterns differing populations or progenies could not be detected, as plants within populations showed a wide range of positions in the figure, usually overlapping

Table 1. Chlorophyll fluorescence parameters averages and standard deviations (Fo, minimal fluorescence yield; Fm, maximal fluorescence yield under a light saturating pulse; Fv/Fm, potential quantum yield of photosystem II; ETRmax, maximum apparent rate of photosynthetic electron transport), analyzed in three populations of $S$. adstringens and a population of C. ferruginea.

\begin{tabular}{lccccc}
\hline Species & Populations & Fo & Fm & Fv/Fm & ETRmax \\
\hline S. adstringens & Piraju & $398 \pm 101$ & $2123 \pm 537$ & $0.811 \pm 0.019$ & $54.4 \pm 17.6$ \\
& Gouvea & $398 \pm 112$ & $2154 \pm 541$ & $0.815 \pm 0.024$ & $50.8 \pm 12.3$ \\
C. ferruginea & Furnas & $381 \pm 115$ & $2094 \pm 540$ & $0.816 \pm 0.036$ & $50.8 \pm 16.6$ \\
& PERD & $665 \pm 90$ & $3079 \pm 245$ & $0.783 \pm 0.023$ & $32.0 \pm 10.2$ \\
\hline
\end{tabular}




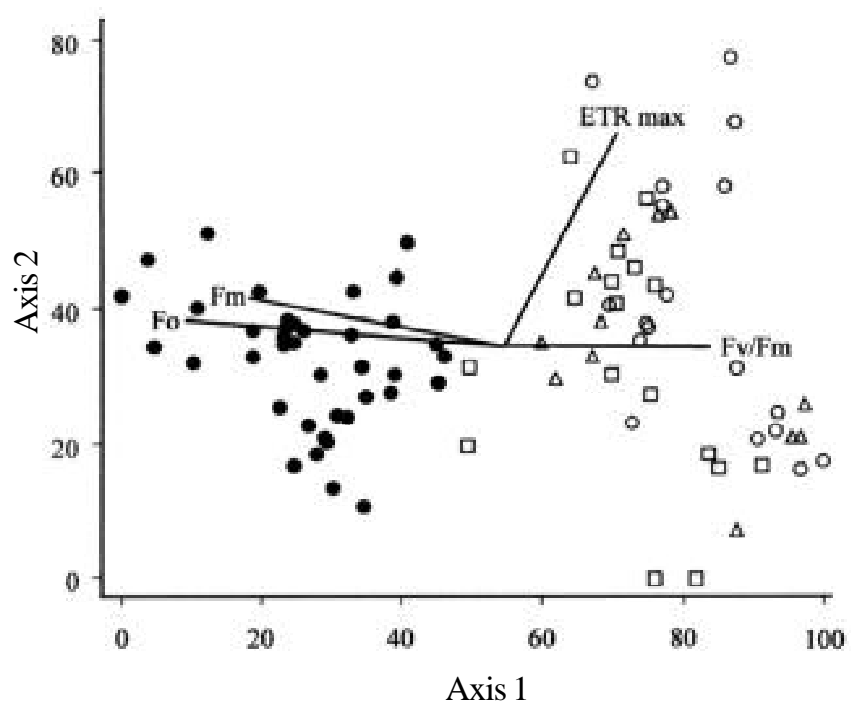

Figure 3. Principal Component Analysis (PCA) considering individuals of three populations of $S$. adstringens (white circles = Piraju, white triangles = Gouveia, white squares $=$ Furnas) and a population of $C$. ferruginea (black circles), and its photosynthesis traits (Fo, minimal fluorescence yield; Fm, maximal fluorescence yield under a light saturating pulse; Fv/Fm, potential quantum yield of photosystem II; ETR max, maximum apparent rate of photosynthetic electron transport).

each other. This pattern agrees with the results found in analysis of variance.

Our results revealed that fluorescence measurements might be considered an efficient technique to distinguish species, but probably not populations or progenies of native tree species, when growing under a non-stressful environment. Similar observations have been reported by Portes \& Magalhães (1993) that could not find differences among genotypes of Phaseolus vulgaris and by Campostrini \& Maestri (1998) that could not distinguish Coffea canephora genotypes in relation to parameters of fluorescence emission. All these results are in agreement with Nicotra et al. (1997) reports, that physiological traits, as photosynthetic performance, are under strong stabilising pressures and so may show little or no genetic variation. Though, it should be noticed that we conducted our experiment in favorable growth environmental conditions and Singsaas et al. (2001) concluded that the intrinsic efficiency of photosynthesis do not vary substantially among plant species or growth conditions, unless plants experience stressful environments. In fact it has been pointed out by many other authors (Havaux \& Lannoye 1985, Selmani \& Wasson 1993, Fragella et al. 1995), that under a stressful situation, genetic differences on chlorophyll fluorescence parameters between populations could be expressed.

Acknowledgments - The authors thank Dr. Cesar Jacoby for helping with the English version of this manuscript. Dra. Cleusa Graça Fonseca helped with data analysis. This work was supported by Fundação de Amparo à Pesquisa do Estado de Minas Gerais (Fapemig) and Brazil Long Term Ecological Research Program - Conselho Nacional de Desenvolvimento Tecnológico (PELD - CNPq). J.P. Lemos Filho received a research fellowship from Conselho Nacional de Desenvolvimento Tecnológico (CNPq).

\section{References}

ALLEN, M.T. \& PEARCY, R.W. 2000. Stomatal behavior and photosynthetic performance under dynamic light regimes in a seasonally dry tropical rain forest. Oecologia 122:470-478.

ARNTZ, A.M. \& DELPH, L.F. 2001. Pattern and process: evidence for the evolution of photosynthetic traits in natural populations. Oecologia 127:455-467.

BARBER, J. \& ANDERSON, B. 1992. Too much of a good thing: light can be bad for photosynthesis. Trends Biochemical Science 17:61-66.

BAZZAZ, F.A. 1979. The physiological ecology of plant succession. Annual Review of Ecology and Systematic 10:351-371.

BILGER, W., SCHREIBER, U. \& BOCK, M. 1995. Determination of the quantum efficiency of photosysthem II and nonphotochemical quenching of chlorophyll fluorescence in the field. Oecologia 102:425-432.

BJÖRKMAN, O. \& DEMMIG-ADAMS, B. 1995. Regulation of photosynthetic light energy capture, convertion and dissipation in leaves of higher plants. In Ecology of photosynthesis (E.D. Schulze \& C.W. Caldwell, eds.). Springer-Verlag, Berlin, p.17-47.

BÒLHAR-NORDENKAMPF, H.R. \& ÖQUIST, G.O. 1993. Chlorophyll fluorescence as a tool in photosynthesis research. In Photosynthesis and production in a changing environment, a field and laboratory manual (D.O. Hall, J.M.O. Scurlock, H.R. Bòlhar-Nordenkampf, R.C. Leegood \& S.P. Long, eds.). Chapman \& Hall, London, p.193-206.

CAMPOSTRINI, E. \& MAESTRI, M. 1998. Photosynthetic potential of five genotypes of Coffea canephora Pierre. Revista Brasileira de Fisiologia Vegetal 10:13-18.

FRAGELLA, Z., PASTORE, D., CAMPANILE, R.G. \& FONZO, N. 1995. The quantum yield of photosynthetic electron transport evaluated by chlorophyll fluorescence as an indicator of drought tolerance in durum wheat. Journal of Agricultural Science 125:325-329. 
FRANCO, A.C. 2000. Water and light use strategies by cerrado woody plants. In Tópicos Atuais em Botânica (T.B. Cavalcanti \& B.M.T. Walter, eds.). Embrapa Recursos Genéticos e Biotecnologia/Sociedade Botânica do Brasil, Brasília, p.292-298.

HAVAUX, M. \& LLANNOYE, R. 1985. Drought resistance of hard wheat cultivars measured by rapid chlorophyll fluorescence test. Journal of Agricultural Science 104:501-504.

HOGAN, K.P., SMITH, A.P. \& SAMANIEGO, M. 1995. Gas exchange in six tropical semi deciduous forest canopy tree species during the wet and dry season. Biotropica 27:324-333.

LEMOS FILHO, J.P. 2000. Fotoinibição de três espécies do cerrado (Annona crassifolia, Eugenia dysenterica e Campomanesia adamantium) na estação seca e na chuva. Revista Brasileira de Botânica 23:45-50.

LÜTTGE, U., HARIDASAN, M., FERNANDES, G.W., MATTOS, E.A., TRIMBORN, P., FRANCO, A.C., CALDAS, L. \& ZIEGLER, H. 1998. Photosynthesis of mistletoes in relation to their hosts at various sites in tropical Brazil. Trees 12:167-174.

MATTOS, E.A. 1998. Perspectives in comparative ecophysiology of some Brazilian vegetation types: leaf $\mathrm{CO}_{2}$ and $\mathrm{H}_{2} \mathrm{O}$ exchange, chlorophyll $a$ fluorescence and carbon isotope discrimination. In Ecophysiological strategies of xerophytic and amphibious plants in the neotropics (F.R. Scarano \& A.C. Franco, eds.). Oecologia brasiliensis, v.4, Universidade Federal do Rio de Janeiro, Rio de Janeiro, p.1-22.

MATTOS, E.A., LOBO, P.C. \& JOLY, C.A. 2002. Overnight rainfall inducing rapid changes in photosynthetic behaviour in a cerrado woody species during a dry spell amidst the rainy season. Australian Journal of Botany 50:241-246.

MIRANDA, A.C., MIRANDA, H.S., LLOYD, J., GRACE, J., FRANCEY, R.J., MCINTYRE, J.A., MEIR, P., TIGGAN, P., LOCKWOOD, R. \& BRASS, J. 1997. Fluxes of carbon, water and energy over Brazilian cerrado: an analysis using eddy covariance and stable isotopes. Plant, Cell and Environment 20:315-328.
MORAES, J.A.P.V. \& PRADO, C.H.B.A. 1998. Photosynthesis and water relations in cerrado vegetation. In Ecophysiological strategies of xerophytic and amphibious plants in the neotropics (F.R. Scarano \& A.C. Franco, eds.). Oecologia brasiliensis, v.4, Universidade Federal do Rio de Janeiro, Rio de Janeiro, p.45-66.

NICOTRA, B.A., CHAZDON, R.L. \& SCHLICHTING, C.D. 1997. Patterns of genotypic variation and phenotypic plasticity of light response in two tropical Piper (Piperaceae) species. American Journal of Botany 84:1542-1552.

PAULA, S.A. \& LEMOS FILHO, J.P. 2001. Dinâmica do dossel em mata semidecídua do perímetro urbano de Belo Horizonte, MG. Revista Brasileira de Botânica 24:545-551.

PAULILO, M.T.S. \& FELIPE, G.M. 1998. Growth of the shrubtree flora of the Brazilian cerrados: a review. Tropical Ecology 39:165-174.

PORTES, T.A. \& MAGALHÃES, A.C.N. 1993. Análise comparativa de diferentes genótipos de feijão através da medição da fluorescência da clorofila e do balanço de $\mathrm{O}_{2}$. Revista Brasileira de Fisiologia Vegetal 5:17-23.

QUEIROZ, C.G.S., GARCIA, Q.S., LEMOS FILHO, J.P. 2002. Atividade fotossintética e peroxidação de lipídios de membrana em plantas de aroeira do sertão sob estresse hídrico. Brazilian Journal of Plant Physiology 14:59-63.

SELMANI, A. \& WASSON, C.E. 1993. Daytime chlorophyll fluorescence measurement in the field grown maize and its genetic variability under well watered and water stresses conditions. Field Crops Research 31:173-184.

ŠESÀK, Z. \& ŠIFFEL, P. 1997. Leaf-age related differences in chlorophyll fluorescence. Photosynthetica 33:347-369.

SINGSAAS, E.L., DONALD, R.O. \& DE LUCIA, E.H. 2001. Variation in measured values of photosynthetic quantum yield in ecophysiological studies. Oecologia 128:15-23.

VALADARES, F., ALLEN, M.T. \& PEARCY, R.W. 1997. Photosynthetic responses to dynamic light under field conditions in six tropical rainforest shrubs occurring along a light gradient. Oecologia 111:505-514. 